\title{
DIMENSI KECERDASAN EMOSIONAL: MEMAHAMI DAN MENDUKUNG EMOSI ORANG LAIN TERHADAP PERILAKU CARING PERAWAT PELAKSANA MENURUT PERSEPSI KLIEN
}

\author{
Anisah Ardiana ${ }^{1,2 *}$, Junaiti Sahar ${ }^{3}$, Dewi Gayatri ${ }^{3}$ \\ 1. Program Studi Ilmu Keperawatan Universitas Jember, Jawa Timur 68121, Indonesia \\ 2. Program Studi Magister Fakultas Ilmu Keperawatan Universitas Indonesia, Depok 16424, Indonesia \\ 3. Fakultas Ilmu Keperawatan Universitas Indonesia, Depok 16424, Indonesia \\ *Email:nyz_rek@yahoo.co.id
}

\begin{abstract}
Abstrak
Kemampuan memahami dan mendukung emosi orang lain memampukan perawat menerima perasaan klien sehingga akan terbentuk hubungan saling percaya, salah satu wujud perilaku caring. Penelitian deskriptif korelasi ini bertujuan mengetahui hubungan dimensi kecerdasan emosional: memahami dan mendukung emosi orang lain dengan perilaku caring perawat menurut persepsi klien. Sampel meliputi 92 perawat pelaksana dan 92 klien. Analisis menggunakan uji Chi-Square dan regresi logistik berganda. Menurut persepsi klien, 54\% perawat berperilaku caring dan 59,8\% perawat memiliki dimensi memahami dan mendukung emosi orang lain. Terdapat hubungan yang signifikan antara dimensi memahami dan mendukung emosi orang lain dengan perilaku caring perawat. Perawat dengan dimensi memahami dan mendukung emosi orang lain yang tinggi berpeluang 2,567 kali lebih caring. Rumah sakit perlu mengembangkan program pelatihan komunikasi efektif dan terapeutik.
\end{abstract}

Kata kunci: caring, kecerdasan emosional, memahami dan mendukung emosi orang lain, perawat, persepsi klien

Abstract

Nurse's caring behavior based on high emotional intelligence can encourage the quality of nursing service. The descriptive correlation research with samples of 92 nurses and 92 patients, was to recognize the relationship between dimension of understanding and support of other people's emotions with nurse's caring behavior according to patients' perceptions. An approximately $54 \%$ of nurses are caring and 59,8\% nurses have dimension of understanding and support of other people's emotions. Chi-Square test showed that the dimension of understanding and support of other people's emotions is significantly associated with nurses caring behavior. Nurses who are having high level in this dimension are having opportunity as much as 2,567 times more caring. A training program on effective and terapheutic communication should be developed.

Keywods: caring, emotional intelligence, understanding and support of other people's emotions, nurse, patients' perception

\section{Pendahuluan}

Era globalisasi telah mendorong persaingan pertumbuhan industri pada semua bidang, termasuk industri pemberi layanan jasa di bidang kesehatan, seperti rumah sakit. Ancaman kehilangan konsumen dapat terjadi jika rumah sakit tidak mampu bersaing secara kualitas maupun biaya. Namun demikian, rumah sakit juga berpeluang memperoleh lebih banyak konsumen jika rumah sakit memiliki kapabilitas menarik animo klien dengan kualitas pelayanan kesehatan yang tinggi atau melebihi harapan klien. Para konsumen pelayanan kesehatan sangat memperhatikan pelayanan kesehatan yang mengutamakan mutu pelayanan yang diberikan oleh suatu rumah sakit (Potter \& Perry, 2005).
Hasil survei terhadap kepuasan klien di salah satu rumah sakit di Bondowoso menunjukkan rata-rata klien puas terhadap pelayanan kesehatan di rumah sakit. Namun demikian, masih ada keluhan klien terhadap pelayanan dan sikap perawat, seperti judes, kurang ramah, jarang senyum, dan jarang menyampaikan informasi yang dibutuhkan klien.

Selain itu, beberapa sikap perawat masih belum mencerminkan dimensi kecerdasan emosional yang baik antara lain tidak bisa menahan emosi, cuek pada keadaan, kurang dapat menerima masukan orang lain, bersikap keras kepada klien, sulit berkoordinasi, sangat bergantung terhadap orang lain dan menghindari tanggung jawab. 
Watson (2005) memandang caring sebagai esensi dari praktik keperawatan yang didasari oleh nilai-nilai kemanusiaan, perhatian, dan kasih sayang terhadap diri sendiri dan orang lain. McQueen (2004) menyampaikan perawat perlu mengadopsi nilai-nilai kecerdasan emosional untuk menciptakan lingkungan emosi yang mendukung hubungan klien-perawat yang kooperatif, sebab dengan kecerdasan emosional, seorang tenaga kesehatan akan lebih empati, memiliki rasa kasih dan lebih bijaksana (Freedman \& Blasé, 2005).

Salah satu dimensi kecerdasan emosional yaitu dimensi memahami dan mendukung emosi orang lain. Kemampuan perawat memahami dan mendukung emosi orang lain (dalam hal ini klien) dapat mendorong perawat untuk menerima perasaan klien baik positif maupun negatif sehingga akan tercipta hubungan saling percaya yang merupakan salah satu wujud perilaku caring perawat.

Perilaku caring perawat yang didasari kecerdasan emosional yang tinggi dapat mendorong pencapaian pelayanan keperawatan yang berkualitas. Di Indonesia, dimensi kecerdasan emosional perawat: memahami dan mendukung emosi orang lain dihubungkan dengan perilaku caring perawat, sejauh yang peneliti ketahui, masih jarang diteliti. Penelitian ini bertujuan mengidentifikasi hubungan salah satu dimensi kecerdasan emosional perawat yaitu memahami dan mendukung emosi orang lain dan perilaku caring perawat pelaksana menurut persepsi klien di ruang rawat inap.

\section{Metode}

Penelitian ini dilaksanakan di ruang rawat inap Rumah Sakit X Bondowoso selama April dan Mei 2010, menggunakan desain deskriptif korelasi dengan pendekatan cross sectional. Populasi dalam penelitian ini menggunakan dua kelompok yaitu perawat dan klien. Kriteria inklusi pada kelompok sampel perawat yaitu: perawat pelaksana di ruang rawat inap, tidak sedang cuti, dan bersedia menjadi responden.

Teknik sampling yang digunakan adalah total sampling. Sedangkan, populasi klien yang digunakan pada penelitian ini adalah semua klien yang dirawat di ruang rawat inap, dengan teknik sampling yaitu pursposive sampling. Kriteria inklusi pada sampel klien yaitu klien dirawat di ruang rawat inap minimal $3 \times 24$ jam, kesadaran composmentis, tingkat ketergantungan self care dan partial care, dan klien bersedia menjadi responden. Untuk kebutuhan generalisasi maka jumlah sampel minimal yang dibutuhkan untuk analisis yaitu 92 perawat dan 92 klien.

Penelitian ini menerapkan prinsip etik penelitian kesehatan mencakup respect for person, beneficience \& non maleficience, dan justice (Hamid, 2008; Komite Nasional Etik Penelitian Kesehatan, 2003). Peneliti menghormati hak responden untuk bebas memutuskan berpartisipasi atau tidak dalam penelitian, tanpa adanya paksaan dari pihak manapun (self determination), ataupun mengakhirikeikutsertaannya sebagai subjek penelitian. Peneliti menjamin kerahasian informasi atau data yang diperoleh dari responden, dan menjaga kerahasiaan identitas responden (anonymity). Peneliti memperlakukan setiap responden dengan adil tanpa memandang gender, bahasa dan usia, serta mengikutsertakan semua data responden yang memenuhi kriteria inklusi mulai dari pengolahan data sampai penyajian data. Responden yang bersedia menjadi subjek penelitian, diminta untuk menandatangani informed consent (formulir persetujuan).

Alat pengumpulan data berupa kuesioner. Kuesioner A dan B mengukur dimensi kecerdasan emosional: menerima dan mendukung emosi orang lain. Kuesioner ini merupakan adopsi dan modifikasi dari dimensi kecerdasan emosional yang dikembangkan oleh Goleman (2005), terdiri dari 83 pertanyaan. Pengembangan kuesioner ini disesuaikan dengan kondisi setempat, menggunakan bahasa yang mudah dimengerti oleh perawat pelaksana. Kuesioner C dan D mengukur perilaku caring perawat menurut persepsi klien diambil dari Caring Assessment Tool (CAT) yang dikembangkan oleh Duffy pada tahun 1990. CAT menggunakan konsep teori Watson dan mengukur 10 faktor karatif. 
Peneliti melakukan beberapa perubahan pada CAT, yaitu hanya item yang relevan yang dipakai dalam kuesioner ini. Hal ini disesuaikan dengan kondisi setempat dan menggunakan bahasa yang mudah dimengerti oleh klien. Kuisioner terdiri dari 41 pertanyaan tertutup dengan pilihan jawaban menggunakan skala Likert 1 - 4 .

\section{Hasil}

Diagram 1. Distribusi Perilaku Caring Perawat Pelaksana Menurut Persepsi Klien

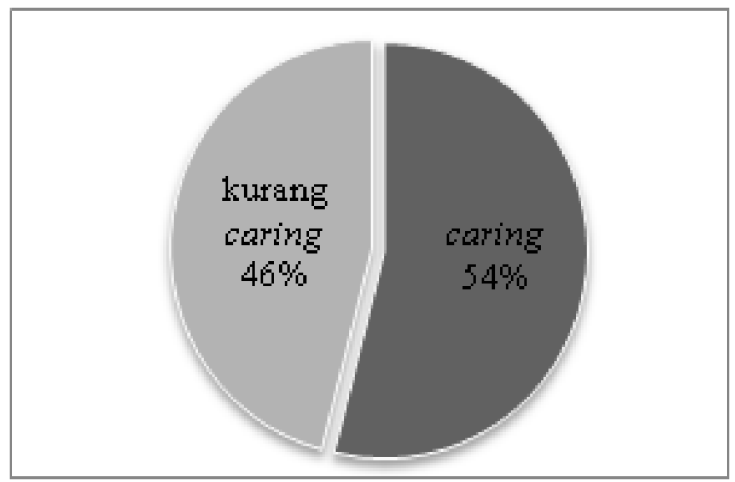

Karakteristik dari 92 responden perawat pada penelitian ini yaitu rata-rata berumur 31,95 tahun dan lama kerja rata-rata 9,78 tahun. Perawat berjenis kelamin laki-laki adalah 31 responden $(33,7 \%)$ dan perempuan 61 responden $(66,3 \%)$. Perawat yang telah menikah adalah 82 responden $(89,1 \%)$ dan belum menikah 10 responden (10,9\%). Perawat berpendidikan D3 Keperawatan adalah 74 responden $(80,4 \%)$, S1 Keperawatan/ Ners yaitu 17 responden $(18,5 \%)$, dan 1 responden berpendidikan SPK $(1,1 \%)$.

Karakteristik dari 92 responden klien pada penelitian ini yaitu rata-rata berumur 41,42 tahun dan lama rawat rata-rata 4,42 hari. Klien berjenis kelamin laki-laki adalah 45 responden $(48,9 \%)$ dan perempuan 47 responden $(51,1 \%)$. Klien yang tidak sekolah adalah 8 responden $(8,7 \%)$, berpendidikan dasar (SD dan SMP) adalah 53 responden $(57,6 \%)$ dan berpendidikan SMA dan Perguruan Tinggi yaitu 31 responden (33,7\%). Sebanyak 73 responden $(79,3 \%)$ telah dirawat satu kali dan 19 responden $(20,7 \%)$ dirawat lebih dari satu kali dalam waktu 5 tahun terakhir.
Proporsi perawat pelaksana yang berperilaku caring menurut persepsi klien yaitu 54\% dan kurang caring $46 \%$ seperti terlihat pada diagram 1 .

Perilaku caring yang sudah baik menurut klien adalah penerapan faktor karatif 1 (humanistik dan altruistik), 3 (kepekaan terhadap diri sendiri dan orang lain), 5 (ungkapan perasaan positif dan negatif), 6 (metode sistematis dalam pemecahan masalah), dan 8 (lingkungan yang supportif dan protektif). Sedangkan, perilaku perawat yang kurang caring terutama terkait komunikasi perawat kepada klien dalam menerapkan faktor karatif 2 (kepercayaan dan harapan), 4 (hubungan saling percaya dan saling membantu), 7 (pembelajaran dan pengajaran dalam hubungan interpersonal), dan 10 (penghargaan kekuatan eksistensial dan fenomenologikal).

Proporsi perawat yang memiliki dimensi memahami dan mendukung emosi orang lain yang tinggi yaitu $59,8 \%$ dan rendah $40,2 \%$ seperti pada grafik 1 .

Dimensi memahami dan mendukung emosi orang lain berhubungan secara signifikan dengan perilaku caring perawat pelaksana menurut persepsiklien ( $\mathrm{p}=0,049$, $\alpha=0,05$ ). Perawat yang memiliki dimensi memahami dan mendukung emosi orang lain berpeluang 2,567 kali lebih caring menurut persepsi klien dibandingkan perawat yang memiki dimensi ini yang rendah. Analisis hubungan dimensi memahami dan mendukung emosi orang lain dengan perilaku caring perawat pelaksana dapat dilihat pada tabel 1 .

Grafik 1. Distribusi Dimensi Memahami dan Mendukung Emosi Orang Lain

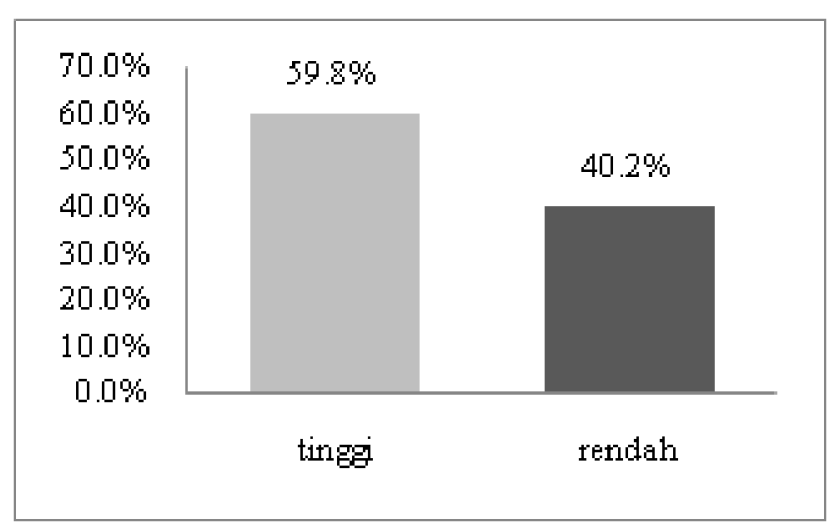


Berdasarkan analisis multivariat diperoleh hasil bahwa hubungan dimensi memahami dan mendukung emosi orang lain dengan perilaku caring perawat pelaksana menurut persepsi klien tidak dipengaruhi oleh karakteristik perawat (umur, jenis kelamin, lama kerja, tingkat pendidikan, dan status pernikahan) maupun karakteristik klien (umur, jenis kelamin, tingkat pendidikan, lama rawat, dan frekuensi dirawat).

\section{Pembahasan}

Hasil uji yang menunjukkan bahwa perilaku caring perawat yang dipersepsikan masih kurang oleh klien adalah terkait dengan komunikasi perawat selama memberikan pelayanan keperawatan pada klien. Perawat belum menerapkan komunikasi terapeutik. Padahal, Stuart dan Laraia (2005) menyebutkan bahwa komunikasi merupakan hal penting yang harus diterapkan dalam praktik keperawatan sebab komunikasi merupakan alat untuk membangun suatu hubungan yang terapeutik. Selain itu, komunikasi bisa menjadi media untuk mempengaruhi perilaku orang lain, sehingga tanpa komunikasi, hubungan terapeutik perawat-klien tidak mungkin terjalin. Hal ini didukung oleh penelitian Kralik, Koch, dan Wotton (1997 dalam Wysong \& Driver, 2009) yang menemukan bahwa aspek perilaku caring yang paling penting menurut persepsi klien post operasi di Australia adalah perawat yang mampu menyatu dengan klien melalui komunikasi terbuka. Watson (2005) menyebutkan bahwa komunikasi yang efektifmerupakan salah satu bentuk hubungan saling percaya.

Perilaku caring yang ditampilkan oleh seorang perawat dapat mempengaruhi kepuasan klien. Wolf, Colahan dan Costello (1998) menemukan adanya hubungan yang signifikan antara perilaku caring perawat dengan kepuasan klien. Perilaku caring perawat tidak hanya mampu meningkatkan kepuasan klien, namun juga dapat menghasilkan keuntungan untuk rumah sakit. Godkin dan Godkin (2004) menyampaikan bahwa perilaku caring dapat mendatangkan manfaat finansial bagi industri pelayanan kesehatan. Issel dan Khan (1998) menambahkan bahwa perilaku caring staf kesehatan mempunyai nilai ekonomi bagi rumah sakit karena perilaku ini berdampak bagi kepuasan klien.

Hasil menunjukkan bahwa 59,8\% perawat memiliki kemampuan memahami dan mendukung emosi orang lain yang tinggi, yaitu dimensi memahami dan mendukung emosi orang lain yang tinggi pada perawat dalam halmengembangkan orang lain, menumbuhkan peluang melalui pergaulan, dan mampu membaca emosi kelompok. Sedangkan yang rendah dalam hal empati (kesadaran terhadap perasaan, perspektif dan kepentingan orang lain) dan orientasi pelayanan (mengantisipasi, mengenali, dan berusaha memenuhi kebutuhan pelanggan).

Peneliti menganalisis kemampuan perawat mengembangkan orang lain, menumbuhkan peluang melalui pergaulan serta membaca emosi kelompok merupakan potensi yang baik. Kemampuan tersebut dapat mendasari perawat dalam merawat klien. Perawat dapat mengembangkan klien untuk melakukan perawatan mandiri sesuai kemampuan diri. Namun, hal ini hendaknya ditunjang dengan empati yang tinggi dan berorientasi pada pelayanan.

Program pengembangan staf dapat dilakukan untuk membudayakan perilaku empati dan orientasi pelayanan (Stuart \& Laraia, 2005), misalnya,

Tabel 1. Analisis Hubungan Dimensi Memahami dan Mendukung Emosi Orang Lain dengan Perilaku Caring Perawat Pelaksana Menurut Persepsi Klien

\begin{tabular}{|c|c|c|c|c|c|c|c|c|}
\hline \multirow{3}{*}{ Karakteristik } & \multicolumn{4}{|c|}{ Perilaku caring } & \multirow{3}{*}{$\begin{array}{c}\text { Jumlah } \\
\text { n }\end{array}$} & \multirow{3}{*}{$x^{2}$} & \multirow{3}{*}{ OR (95\% CI) } & \multirow{3}{*}{$\mathbf{p}$} \\
\hline & \multicolumn{2}{|c|}{ Kurang caring } & \multicolumn{2}{|c|}{ Caring } & & & & \\
\hline & $\mathbf{n}$ & $\%$ & $\mathbf{N}$ & $\%$ & & & & \\
\hline Rendah & 22 & 59,5 & 15 & 40,5 & 37 & 3,87 & 1 & 0,049 \\
\hline T inggi & 20 & 36,4 & 35 & 63,6 & 55 & & $\begin{array}{c}2,567 \\
(1,09-6,04)\end{array}$ & \\
\hline
\end{tabular}


pelatihan dan penyegaran tentang empati, komunikasi efektif dan komunikasi terapeutik baik untuk perawat lama maupun perawat baru sehingga secara keseluruhan perawat dapat dinilai empati oleh klien.

Hasil analisis bivariat diketahui bahwa ada hubungan yang bermakna antara dimensi memahami dan mendukung emosiorang lain yang dimiliki oleh perawat pelaksana dengan perilaku caring perawat pelaksana menurut persepsi klien. Dari hasil interpretasi ini, dapat dikatakan bahwa kemampuan perawat memahami dan mendukung emosi orang lain terbukti dapat mempengaruhi perilaku caring perawat pelaksana menurut persepsi klien.

Perawat yang memiliki kemampuan yang tinggi dalam memahami dan mendukung emosi orang lain, dipersepsikan lebih caring oleh klien dibandingkan dengan perawat yang memiliki kemampuan yang rendah dalam hal memahami dan mendukung emosi orang lain yakni sebesar $63,6 \%$.Analisis lebih lanjut menunjukkan bahwa perawat yang memiliki kemampuan memahami dan mendukung emosi orang lain berpeluang 2,567 kali dipersepsikan lebih caring oleh klien dibandingkan perawat yang memiliki kemampuan yang rendah dalam hal memahami dan mendukung emosi orang lain.

Hal ini sesuai dengan pendapat Bar-on (2007) yang menyatakan bahwa kemampuan individu memahami perasaan orang lain akan mendorong individu untuk bersikap empati (memahami dan mengerti perasaan orang lain) dan mampu membangun hubungan yang memuaskan diri sendiri dan orang lain. Individu yang mampu memahami dan mendukung emosi orang lain akan lebih mampu memahami perasaan, pikiran dan situasi yang dirasakan oleh orang lain (McShane \& Glinow, 2003), mampu memahami perspektif orang lain, menumbuhkan saling percaya dan menyelaraskan diri dengan orang lain (Goleman, 2005). Dengan empati kepada klien, maka perawat akan lebih mampu menunjukkan rasa kasih terhadap klien dalam setiap keputusan dan tindakannya yang merupakan aspek penting dalam pelayanan keperawatan.

Peneliti menganalisis bahwa kemampuan perawat dalam memahami dan mendukung emosi orang lain akan mendorong terciptanya hubungan perawat-klien yang terbuka, saling percaya, saling menghargai perasaan dan pengalaman perawat dan klien. Mengembangkan hubungan saling percaya dan saling membantu antara perawat dan klien merupakan hal yang sangat penting dalam transpersonal caring (Watson, 2005). Klien mengharapkan perilaku caring yang holistik sehingga klien puas dengan pelayanan keperawatan. Jadi, dengan kemampuan perawat memahami dan mendukung emosi orang lain (dalam hal ini klien) maka dapat mendorong perawat untuk menerima perasaan klien baik positif maupun negatif sehingga akan tercipta hubungan saling percaya yang merupakan salah satu wujud perilaku caring perawat.

Peneliti menganalisis bahwa penerapan komunikasi terapeutik perawat mempengaruhi hasil dari penelitian ini. Tempat penelitian, yang tidak semua perawatnya menerapkan komunikasi terapeutik, dapat mempengaruhi penilaian caring perawat oleh klien. Untuk itu, perlu dikembangkan replikasi penelitian ini untuk memastikan hubungan kecerdasan emosional dengan perilaku caring perawat menurut persepsi klien yang dilakukan di tempat penelitian (rumah sakit) yang penerapan komunikasi terapeutiknya sudah baik. Selain itu, dapat dilakukan penelitian lebih lanjut yang mengidentifikasi pengaruh kecerdasan intelektual, emosional dan spiritual terhadap performa perawat termasuk perilaku caring.

\section{Kesimpulan}

Hasil penelitian ini menyimpulkan bahwa perilaku caring perawat yang masih kurang menurut persepsi klien yaitu komunikasi. Ditemukan adanya hubungan yang signifikan antara dimensi kecerdasan emosional: memahami dan mendukung emosi orang lain dengan perilaku caring perawat menurut persepsi klien. Perawat yang memiliki dimensi ini dipersepsikan lebih caring oleh klien yaitu $63,6 \%$ perawat.

Perilaku caring yang didasari dengan kecerdasan emosional yang baik akan mendukung terciptanya pelayanan keperawatan yang sesuai dengan harapan klien. Klien yang menerima pelayanan tenaga kesehatan dengan keterampilan sempurna, 
namun tidak disertai dengan sikap emosi yang baik dalam pelayanannya, maka pelayanan tersebut dinilai klien sebagai pelayanan yang tidak adekuat (MS, JS, YA).

\section{Referensi}

Bar-on, R. (2007). Bar-on model of emotional-social intelligence. Diperoleh dari http://www. reuvenbaron.org/bar-on-model/essay.php? $\mathrm{i}=3$ \#intra.

Freedman, J., \& Blasé, K. (2005). Interview: Emotional intelligence with Dr. Daniel Goleman. Diperoleh dari http://www.6seconds. org $/$ modules.php? name $=$ News $\&$ file $=$ article $\& \operatorname{sid}=212$.

Godkin, J., \& Godkin, L. (2004). Caring behaviors among nurses: Fostering a conversation of gestures. Journal Health Care Management Review, 29 (3), 258-267.

Goleman, D. (2005). Emotional intelligence. New York: Bantam Dell.

Hamid, A.Y.S. (2008). Buku ajar riset keperawatan (Edisi 2). Jakarta: EGC.

Issel, L.M., \& Khan, D. (1998). The economic value of caring. Journal Health Care Management Review, 23 (4), 43-53.
Komite Nasional Etik Penelitian Kesehatan. (2003). Pedoman nasional etik penelitian kesehatan. Disampaikan pada Rapat Kerja I pada 18-19 Februari 2003, Jakarta.

McQueen, A.C. (2004). Emotional intelligence in nursing work. Journal of Advanced Nursing, 47 (1), 101-108.

McShane, S.L., \& Glinow, M.A.V. (2003). Organizational behavior: Emerging realities for the workplace revolution. North America: McGraw-Hill.

Potter, P.A., \& Perry, A.G. (2005). Buku ajar fundamental keperawatan: Konsep, proses dan praktik (Penerjemah: Yasmin Asih, dkk.) (Edisi 4). Jakarta: EGC.

Stuart, G. W., \& Laraia, M. T. (2005). Principles and pratice of psychiatric nursing (8th Edition). Missouri: Mosby.

Watson, J. (2005). Caring science as sacred science. USA: F. A. Davis Company.

Wolf, Z.R., Colahan, M., \& Costello, A. (1998). Relationship between nurse caring and patient satisfaction. Journal Medsurg Nurs, 7 (2), 99105.

Wysong, P.R., \& Driver, E. (2009). Patients' perceptions of nurses' skill. Journal Critical Care Nurse, 29, 24-37.

Saya mempelajari kehidupan pria dan wanita besar,

dan saya menjumpai bahwa pria dan wanita yang mencapai puncak adalah yang melakukan pekerjaan yang ada ditangannya, dengan segala energi, semangat dan kerja keras yang mereka punya.

- Harry S. Truman -

Anda harus menang dalam pikiran sebelum menang dalam kehidupan

- John addison - 